\title{
Electrical Conductivity Test to Evaluate the Physiological Quality of Salvia hispanica $\mathrm{L}$. Seeds
}

\author{
A. K. Radke ${ }^{1}$, D. W. Maass ${ }^{1}$, M. S. Pieper ${ }^{1}$, F. M. Xavier ${ }^{1}$, A. B. N. Martins ${ }^{1}$, R. O. Vergara ${ }^{1}$, F. A. Villela ${ }^{1}$ \\ \& G. E. Meneghello ${ }^{1}$ \\ ${ }^{1}$ Federal University of Pelotas, Capão do Leão, RS, Brazil \\ Correspondence: A. K. Radke, Federal University of Pelotas, Capão do Leão, P.O. Box 354, CEP 960001-970, \\ RS, Brazil. E-mail: alinekradke@hotmail.com
}

\author{
Received: December 5, $2017 \quad$ Accepted: January 24, $2018 \quad$ Online Published: February 15, 2018 \\ doi:10.5539/jas.v10n3p377 URL: https://doi.org/10.5539/jas.v10n3p377
}

The research is financed by CNPq, National Council of Scientific and Technological Development of Brazil.

\begin{abstract}
Chia (Salvia hispanica L.) is an herbaceous plant that belongs to the Lamiaceae family. Seed vigor testing is an important component of quality control programs, and electrical conductivity test is a possible option in this process. The objective of this study was to identify a methodology of electrical conductivity test to stratify chia seed lots at vigor level according to the emergence of seedlings. Six lots of chia seeds were used in this study. The seeds were exposed to the following determinations: first germination count, germination, emergence speed index, emergence, aerial and root length, aerial and root dry matter, and electrical conductivity at 25, 50 and 75 $\mathrm{mL}$ during 1, 2, 4, 6, 8 and 24 hours of soaking in water. The electrical conductivity test in the combination of 25 seeds using $50 \mathrm{~mL}$ of water in 6-hour of soaking period, as well as the combination of 50 seeds using $50 \mathrm{~mL}$ of water for 24 hours of soaking, were efficient in the stratification of chia seeds in different levels of vigor.
\end{abstract}

Keywords: chia, physiological quality, seeds, vigor

\section{Introduction}

Chia (Salvia hispanica L.) is an herbaceous plant that belongs to the Lamiaceae family, which also includes mint (Mentha spicata), thyme (Thymus vulgaris) and rosemary (Rosmarinus officinalis) (Garcéz, 2013). Chia is an oil palm native to the region that extends from Midwest Mexico to northern Guatemala. This specie is notable for its adaptation to regions of tropical and subtropical climate (Capitanni, Sportorno, Nolasco, \& Tomás, 2012).

In recent years, concerns about healthy eating have contributed to the increase demand for nutrient-rich food that contains beneficial substances for the body. The nutritional properties of chia seed makes it an excellent source of important substances such as Omega-3, fiber and calcium, making it highly recommended as a complement in the food menu (Souza \& Chaves, 2016).

The seed quality is evaluated by the sum of genetic, physical, physiological and health attributes which are determined by the analysis of a representative sample of a lot (Vazquez, Bertolin, \& Spegiorin, 2011). In this sense, germination and vigor tests are essential components of the process of quality control in companies processing seeds (Torres, Paiva, Almeida, Benedito, \& Carvalho, 2015).

The electrical conductivity test is a test of vigor considered fast, which indirectly evaluates the quality of the seeds. The level of seed deterioration can be measure by seeds hydration which will exude ions, sugar and other metabolites at the beginning of imbibition period. That occurs due to changes in the cell membrane integrity (Carvalho \& Novembre, 2011). Therefore, those with less vigor release more leachate as a consequence of the lower structure and selectivity of the membranes (Vieira, Penariol, Perecin, \& Panobianco, 2002).

Seeds with low vigor tend to present disorganization cell membranes structure which allows an increase in solute leaching (McDonald, 1999). Studies have shown that the decrease in germination and vigor is directly proportional to the increase in the concentration of electrolytes released by the seeds during imbibition (Martins, Martinelli-Senem, Castro, Nakagawa, \& Cavariani, 2002). 
Researchers have sought to adapt methodologies for the electrical conductivity test for different species (Cruz et al., 2013). Depending on the species under study, there may be variation in the amount of seed used, volume of deionized water and seed imbibition time (Milani, Menezes, \& Lopes, 2012).

The objective of this study was to determine a methodology of electrical conductivity test that stratifies chia seed lots at vigor levels according to the emergence of seedlings.

\section{Materials and Methods}

The study was realized at Federal University of Pelotas, Faculty of Agronomy (FAEM/UFPEL) in the Laboratory of Seed Analysis and in the greenhouse. A total of six lots of untreated chia seeds were used, which were evaluated for the following determinations:

Water content-conducted according to RAS (Brazil, 2009), by the greenhouse method at $105 \pm 3{ }^{\circ} \mathrm{C}$, for 24 hours. The results were expressed as a percentage on a wet basis. The water content of the seeds when conducting the conductivity test is an extremely important factor in the standardization of the test methodology, as well as the possibility of obtaining uniform results between laboratories and inside a laboratory, when there is more than one person performing the test (Vieira \& Krzyzanowski, 1999).

Germination-200 seeds (four subsamples of 50 seeds) were used for each sample distributed evenly over two sheets of blotting paper inside gerbox-type plastic boxes. The seeds were moistened with water equivalent to 2.5 times their weight. The gerboxs were kept in germinator at $20^{\circ} \mathrm{C}$. Germination counts were performed at four and seven days (Adapted from Stefanello, Neves, Abbad, \& Viana, 2015). The results were expressed as mean percentage of normal seedlings for each lot.

First count of the germination - was carried out in conjunction with the germination test and the count was performed at four days.

Emergence of seedlings in greenhouse - four replicates of 50 seeds were used and distributed in plastic trays containing substrate. Irrigations were used whenever necessary to supply water for seed germination and emergence of seedlings. Trays were kept in greenhouse without control of temperature and relative humidity. Evaluation of number of emerged seedlings was performed on the fourteenth day after sowing.

Aerial and root length-four subsamples of 15 seeds were used in each sample. The seeds were sown in the upper third of the germitest paper and moistened with water equivalent to 2.5 times its dry mass. The seeds were kept in germinator at $25{ }^{\circ} \mathrm{C}$ (Nakagawa, 1999). The measurement of 10 seedlings were performed on the tenth day after sowing using a millimeter ruler, the result was expressed in centimeters.

Aerial and root dry shoot biomass-10 normal seedlings obtained in the shoot length and root length were evaluated. Samples from each batch were separated into aerial part and root system, packed in identified paper bags and brought to the oven with air circulation at $65^{\circ} \mathrm{C}$ for a period of 72 hours (Nakagawa, 1999). After this period, each replicate had the mass weighed on a scale with an accuracy of $0.001 \mathrm{~g}$. Theresults were expressed in milligrams per seedling.

\subsection{Alternative Test for Physiological Quality Evaluation}

Considering the routine organization of the activities of a seed analysis laboratory, the 24-hour imbibition period is recommended. However, it is important, in work with other species, considered small seeds, such as vegetables, the imbibition period may be less (Vieira \& Krzyzanowski, 1999). Thus, tests were carried out with different combinations of time, volume and quantity of seeds.

Electrical conductivity-four seed subsamples were used for each batch. The combination of imbibition periods $(1,2,4,6,8$ and 24 hours), deionized water volume $(25,50$ and $75 \mathrm{~mL})$ and number of seeds $(25$ and 50$)$ at imbibition of $20^{\circ} \mathrm{C}$ were used in this experiment. In order to have the blank reading for the water, an initial electrical conductivity content of the water was measured. The seed samples were weighed in a precision balance of $0.0001 \mathrm{~g}$, to obtain the seed mass for each sample. After being weighed, the seeds were placed to soak in plastic cups containing deionized water in the pre-established volumes. The cups were kept in a germination room with controlled temperature of $20^{\circ} \mathrm{C}$. The electrical conductivity readings were performed using a device called conductivity meter (model Digimed DM-31). The readings were performed after each combinations of seed number and water volume. The result obtained in the conductivity minus the blank test was divided by the mass of each seed repetition, and expressed in $\mu \mathrm{S} \mathrm{cm}^{-1} \mathrm{~g}^{-1}$. The average values obtained for reading in each batch were expressed in $\mu \mathrm{S} \mathrm{m}^{-1} \mathrm{~g}^{-1}$. 


\subsection{Experimental Design}

The experimental design was a completely randomized design with four replications. The Tukey test was performed with $5 \%$ probability of error and Pearson correlation analysis was performed to assess the correlation between seedling emergence and the different methodologies for electrical conductivity test.

\section{Results and Discussion}

Data on the water content of chia seeds were similar for the five batches with variations between $6.8 \%$ and $7.0 \%$ (Table 1). The water content data was not statistically analyzed and was used only for the initial characterization of chia seed lots.

In the germination test was not possible to verify differences between the lots evaluated (Table 1). In the first germination test, seed lots of chia did not differ for the different levels of vigor. However, the use of other tests were more sensitive and efficient in detecting the first signs of seed deterioration.

Seedling emergence results indicated a significant difference between the lots which allowed the classification of lots 3 and 6 as the ones with the greatest vigor with seedling emergence of 96\%. Lots 1, 2, 4 and 5 had lower vigor with emergence of seedlings around $84 \%$ (Table 1). Seedling emergence can be considered as the main reference for the stratification of seed lots at vigor levels, which can be understood by the amount of energy a seed has available for rapid and uniform germination with adequate establishment of seedlings under various environmental conditions (Souza, Villela, \& Aumonde, 2013).

Length of aerial part was possible to identify lot 6 as being the most vigorous when compared with the others lots in this study. In the other hand, the root length and dry shoot phytomass of aerial part showed similar distribution of chia lots, where lots 3 and 6 had superior quality. However, in the evaluation of root dry matter all lots showed similar results.

Table 1. Initial quality of seed lots of chia seeds by water content (WC), germination test (G), first germination count (FGC), seedling emergence (SE), shoot length (SL), root length (RL), dry matter (DM) and root dry matter (RDM) of six seed lots

\begin{tabular}{lllllllll}
\hline Lote & WC & G $(\%)$ & FGC $(\%)$ & SE $(\%)$ & SL $(\mathrm{cm})$ & RL $(\mathrm{cm})$ & DM $(\mathrm{mg})$ & RDM $(\mathrm{mg})$ \\
\hline 1 & 7.0 & $90 \mathrm{~A}$ & $77 \mathrm{~A}$ & $81 \mathrm{~B}$ & $3.76 \mathrm{~B}$ & $4.54 \mathrm{AB}$ & $0.0515 \mathrm{AB}$ & $0.0905 \mathrm{~A}$ \\
2 & 6.8 & $88 \mathrm{~A}$ & $76 \mathrm{~A}$ & $87 \mathrm{~B}$ & $3.76 \mathrm{~B}$ & $4.52 \mathrm{AB}$ & $0.0442 \mathrm{~B}$ & $0.0997 \mathrm{~A}$ \\
3 & 6.9 & $94 \mathrm{~A}$ & $84 \mathrm{~A}$ & $95 \mathrm{~A}$ & $4.38 \mathrm{AB}$ & $5.23 \mathrm{~A}$ & $0.0570 \mathrm{~A}$ & $0.1125 \mathrm{~A}$ \\
4 & 6.9 & $89 \mathrm{~A}$ & $77 \mathrm{~A}$ & $85 \mathrm{~B}$ & $3.82 \mathrm{~B}$ & $3.83 \mathrm{~B}$ & $0.0500 \mathrm{AB}$ & $0.0977 \mathrm{~A}$ \\
5 & 7.0 & $87 \mathrm{~A}$ & $76 \mathrm{~A}$ & $84 \mathrm{~B}$ & $4.19 \mathrm{AB}$ & $4.31 \mathrm{AB}$ & $0.0432 \mathrm{~B}$ & $0.0982 \mathrm{~A}$ \\
6 & 7.0 & $96 \mathrm{~A}$ & $82 \mathrm{~A}$ & $96 \mathrm{~A}$ & $4.70 \mathrm{~A}$ & $4.98 \mathrm{~A}$ & $0.0550 \mathrm{~A}$ & $0.1245 \mathrm{~A}$ \\
$\mathrm{CV}(\%)$ & - & 4.36 & 5.98 & 4.09 & 8.70 & 9.33 & 8.61 & 15.48 \\
\hline
\end{tabular}

Note. $\mathrm{WC}=$ water content; $\mathrm{G}=$ germination test $\mathrm{FGC}=$ first germination count; $\mathrm{SE}=$ seedling emergence; $\mathrm{SL}=$ shoot length; $\mathrm{RL}=$ root length; $\mathrm{DM}=$ dry matter; $\mathrm{RDM}=$ root dry matter. Averages followed by the same letter in the column do not differ statistically by Tukey test at $5 \%$ probability. CV: coefficient of variation.

In Table 2 shows the results for 25 seeds in the treatments of 25,50 and $75 \mathrm{~mL}$ during 1 hour of imbibition., There was not differences for the seed lots for the different vigor levels. This fact could be attributed to the relatively short period of time which was not enough for membrane organization and release of leachate. In a study with sesame seeds, Torres and Bezerra Neto (2009) found that for the various combinations, water volume/temperature/ imbibition period, generally indicated an increase in the amount of leached electrolytes in the range of 1 to 24 hours, as the imbibition period increased.

For the electrical conductivity test using 25 seeds and $25 \mathrm{~mL}$ of water volume for the seed imbibition there was no stratification of the lots (Table 2). Regarding the vigor, similarly to the emergency test, by means of the test of electrical conductivity as clearly as observed in the combination of 25 seeds $50 \mathrm{~mL}^{-1}$ of distilled water for 6 hours of soaking.

A more precise analysis of seed quality requires a complementation of the information supplied by the germination with vigor tests to allow selection of the best lots for commercialization and sowing (Araujo et al., 2011). 
Table 2 . The average electrical conductivity data $\left(\mu \mathrm{S} \mathrm{cm}^{-1} \mathrm{~g}^{-1}\right)$ using the combinations 25 seeds 25,50 and 75 $\mathrm{mL}^{-1}$ per $1,2,4,6,8$ and 24 hours of imbibition at $20^{\circ} \mathrm{C}$ of six lots of chia seeds

\begin{tabular}{|c|c|c|c|c|c|c|}
\hline \multirow{2}{*}{ Lots } & \multicolumn{6}{|c|}{ Period of soaking (hours) } \\
\hline & 1 & 2 & 4 & 6 & 8 & 24 \\
\hline \multicolumn{7}{|l|}{$25 \mathrm{~mL}$} \\
\hline 1 & $365.846 \mathrm{~A}$ & $411.157 \mathrm{AB}$ & $428.000 \mathrm{~A}$ & $462.53 \mathrm{~A}$ & $487.405 \mathrm{AB}$ & $561.355 \mathrm{AB}$ \\
\hline 2 & $401.207 \mathrm{~A}$ & $406.578 \mathrm{AB}$ & $432.058 \mathrm{~A}$ & $475.603 \mathrm{~A}$ & $528.077 \mathrm{~B}$ & $607.817 \mathrm{~B}$ \\
\hline 3 & $322.000 \mathrm{~A}$ & $379.026 \mathrm{~A}$ & $404.547 \mathrm{~A}$ & $447.968 \mathrm{~A}$ & $464.679 \mathrm{~A}$ & $534.633 \mathrm{AB}$ \\
\hline 4 & $364.395 \mathrm{~A}$ & $408.452 \mathrm{AB}$ & $418.345 \mathrm{~A}$ & $453.804 \mathrm{~A}$ & $453.983 \mathrm{~A}$ & $518.782 \mathrm{~A}$ \\
\hline 5 & $388.042 \mathrm{~A}$ & $438.100 \mathrm{~B}$ & $440.172 \mathrm{~A}$ & $477.842 \mathrm{~A}$ & $493.662 \mathrm{AB}$ & $580.001 \mathrm{AB}$ \\
\hline 6 & $345.288 \mathrm{~A}$ & $391.190 \mathrm{~A}$ & $405.585 \mathrm{~A}$ & $439.952 \mathrm{~A}$ & $460.237 \mathrm{~A}$ & $531.112 \mathrm{AB}$ \\
\hline CV $(\%)$ & 11.169 & 4.37 & 4.79 & 5.36 & 4.67 & 7.01 \\
\hline \multicolumn{7}{|l|}{$50 \mathrm{~mL}$} \\
\hline 1 & $99.098 \mathrm{~A}$ & $146.689 \mathrm{~A}$ & $230.083 \mathrm{BC}$ & $276.323 \mathrm{~B}$ & $309.782 \mathrm{AB}$ & $460.403 \mathrm{ABC}$ \\
\hline 2 & $89.673 \mathrm{~A}$ & $149.931 \mathrm{~A}$ & $235.210 \mathrm{C}$ & $283.395 \mathrm{~B}$ & $322.172 \mathrm{~B}$ & $477.066 \mathrm{C}$ \\
\hline 3 & $90.260 \mathrm{~A}$ & $136.503 \mathrm{~A}$ & $201.929 \mathrm{AB}$ & $256.082 \mathrm{~A}$ & $294.591 \mathrm{AB}$ & $419.995 \mathrm{~A}$ \\
\hline 4 & $96.193 \mathrm{~A}$ & $142.083 \mathrm{~A}$ & $219.015 \mathrm{ABC}$ & 265.594 B & $289.901 \mathrm{AB}$ & 474.366 BC \\
\hline 5 & $91.608 \mathrm{~A}$ & $146.597 \mathrm{~A}$ & $224.668 \mathrm{ABC}$ & $277.521 \mathrm{~B}$ & $305.000 \mathrm{AB}$ & $437.495 \mathrm{ABC}$ \\
\hline 6 & $89.976 \mathrm{~A}$ & $137.631 \mathrm{~A}$ & $209.272 \mathrm{~A}$ & $247.754 \mathrm{~A}$ & $286.110 \mathrm{~A}$ & $428.679 \mathrm{AB}$ \\
\hline CV (\%) & 5.91 & 4.51 & 4.03 & 3.15 & 4.82 & 4.64 \\
\hline \multicolumn{7}{|l|}{$75 m L$} \\
\hline 1 & $37.434 \mathrm{~A}$ & $63.695 \mathrm{~A}$ & $92.95 \mathrm{~A}$ & $126.281 \mathrm{ABC}$ & $149.928 \mathrm{ABC}$ & $237.198 \mathrm{~B}$ \\
\hline 2 & $41.635 \mathrm{~A}$ & $66.822 \mathrm{~A}$ & $101.661 \mathrm{~B}$ & $137.382 \mathrm{C}$ & $158.239 \mathrm{C}$ & $247.071 \mathrm{~B}$ \\
\hline 3 & $36.309 \mathrm{~A}$ & $59.023 \mathrm{~A}$ & $90.337 \mathrm{~A}$ & $121.530 \mathrm{AB}$ & $144.586 \mathrm{AB}$ & 236.977 B \\
\hline 4 & $38.049 \mathrm{~A}$ & $62.262 \mathrm{~A}$ & $93.53 \mathrm{AB}$ & $124.451 \mathrm{AB}$ & $148.421 \mathrm{ABC}$ & $238.421 \mathrm{~B}$ \\
\hline 5 & $35.894 \mathrm{~A}$ & $58.392 \mathrm{~A}$ & $93.08 \mathrm{~A}$ & $127.560 \mathrm{BC}$ & $150.337 \mathrm{BC}$ & 248.795 B \\
\hline 6 & $36.721 \mathrm{~A}$ & $58.655 \mathrm{~A}$ & $87.45 \mathrm{~A}$ & $116.108 \mathrm{~A}$ & $138.047 \mathrm{~A}$ & $222.026 \mathrm{~A}$ \\
\hline CV (\%) & 9.66 & 6.25 & 3.98 & 3.98 & 3.63 & 2.73 \\
\hline
\end{tabular}

Note. Averages followed by the same letter in the column do not differ statistically by Tukey test at $5 \%$ probability. CV: coefficient of variation.

In the combination of 25 seeds $50 \mathrm{~mL}^{-1}$ of deionized water in the 6-hour periods as well as 50 seeds per 24 hours (Table 3), we highlighted lots 3 and 6 as the most vigorous and lots 1, 2, 4 and 5 as vigor, according to the physiological characterization of the seed lots using the seedling emergence test (Table 1).

During the imbibition process, seeds with low vigor require a greater amount of nutrients such as sugars, amino acids and fatty acids which are essential for the restoration of cell membranes and reactivation of metabolism. Thus, seeds with lower physiological potential tend to present higher leaching of inorganic ions and enzymes (Vanzolini \& Nakagawa, 2005)

For the combination of 25 seeds or 50 seeds using $75 \mathrm{~mL}$ of deionized water, it was not possible to stratify lots similar to the seedling emergence test.

According to the reduction of water volume in the electrical conductivity test, the number of seeds and the imbibition period were constant. Increase in leaching values was observed. These results are similar to those observed by Torres and Pereira (2010) in arugula seeds. The leachate values decreased as the water volume increased in the test a fact attributed to the dilution caused by the increase in the amount of water used to imbibe the seeds. 
Table 3. Average electrical conductivity data $\left(\mu \mathrm{S} \mathrm{cm}^{-1} \mathrm{~g}^{-1}\right)$ using the combinations 50 seeds 25,50 and $75 \mathrm{~mL}^{-1}$ per $1,2,4,6,8$ and 24 hours of imbibition at $20^{\circ} \mathrm{C}$ of five lots of chia seeds

\begin{tabular}{|c|c|c|c|c|c|c|}
\hline \multirow{2}{*}{ Lots } & \multicolumn{6}{|c|}{ Period of soaking (hours) } \\
\hline & 1 & 2 & 4 & 6 & 8 & 24 \\
\hline \multicolumn{7}{|l|}{$25 \mathrm{~mL}$} \\
\hline 1 & $647.992 \mathrm{AB}$ & $687.159 \mathrm{~B}$ & $724.323 \mathrm{AB}$ & $789.905 \mathrm{BC}$ & $802.060 \mathrm{BC}$ & $859.054 \mathrm{~B}$ \\
\hline 2 & $651.149 \mathrm{AB}$ & $732.911 \mathrm{~B}$ & $795.396 \mathrm{~B}$ & $705.859 \mathrm{BC}$ & $808.793 \mathrm{BC}$ & $905.408 \mathrm{BC}$ \\
\hline 3 & $545.434 \mathrm{~A}$ & $587.038 \mathrm{~A}$ & $610.978 \mathrm{~A}$ & $662.084 \mathrm{~A}$ & $686.041 \mathrm{~A}$ & $764.055 \mathrm{~A}$ \\
\hline 4 & $673.101 \mathrm{AB}$ & $738.481 \mathrm{~B}$ & $780.396 \mathrm{~B}$ & $833.253 \mathrm{C}$ & $858.946 \mathrm{C}$ & $969.059 \mathrm{C}$ \\
\hline 5 & $689.912 \mathrm{C}$ & $706.576 \mathrm{~B}$ & $758.283 \mathrm{~B}$ & $794.167 \mathrm{BC}$ & $813.571 \mathrm{BC}$ & $935.389 \mathrm{BC}$ \\
\hline 6 & 616.945 B & $693.179 \mathrm{~B}$ & $717.831 \mathrm{AB}$ & $750.335 \mathrm{AB}$ & $772.158 \mathrm{~B}$ & $857.331 \mathrm{~B}$ \\
\hline $\mathrm{CV}(\%)$ & 4.73 & 5.64 & 6.93 & 4.5 & 4.79 & 4.16 \\
\hline \multicolumn{7}{|l|}{$50 \mathrm{~mL}$} \\
\hline 1 & $186.584 \mathrm{C}$ & $255.930 \mathrm{CD}$ & $388.825 \mathrm{CD}$ & $478.208 \mathrm{C}$ & $521.3 \mathrm{BC}$ & $712.462 \mathrm{~B}$ \\
\hline 2 & $144.721 \mathrm{AB}$ & $230.977 \mathrm{BC}$ & $360.906 \mathrm{BC}$ & $436.078 \mathrm{BC}$ & $501.939 \mathrm{BC}$ & 730.775 B \\
\hline 3 & $134.450 \mathrm{~A}$ & $193.766 \mathrm{~A}$ & $308.229 \mathrm{~A}$ & $353.97 \mathrm{~A}$ & $409.694 \mathrm{~A}$ & $575.487 \mathrm{~A}$ \\
\hline 4 & $189.707 \mathrm{C}$ & $275.411 \mathrm{D}$ & $406.402 \mathrm{D}$ & $478.105 \mathrm{C}$ & $540.044 \mathrm{C}$ & $759.905 \mathrm{~B}$ \\
\hline 5 & $163.520 \mathrm{BC}$ & $245.230 \mathrm{CD}$ & $372.563 \mathrm{BC}$ & $444.985 \mathrm{BC}$ & $526.010 \mathrm{~A}$ & $744.714 \mathrm{~B}$ \\
\hline 6 & $141.778 \mathrm{AB}$ & $209.702 \mathrm{AB}$ & $330.503 \mathrm{AB}$ & $385.714 \mathrm{AB}$ & $454.956 \mathrm{AB}$ & $652.493 \mathrm{~A}$ \\
\hline CV (\%) & 7.35 & 6 & 5.59 & 6.33 & 6.41 & 4.5 \\
\hline \multicolumn{7}{|l|}{$75 \mathrm{~mL}$} \\
\hline 1 & $30.285 \mathrm{~A}$ & $64.124 \mathrm{~A}$ & $132.203 \mathrm{~B}$ & $161.688 \mathrm{AB}$ & $219.027 \mathrm{~B}$ & $343.288 \mathrm{~B}$ \\
\hline 2 & $44.572 \mathrm{~B}$ & $83.895 \mathrm{AB}$ & $131.162 \mathrm{~B}$ & $169.932 \mathrm{AB}$ & $204.178 \mathrm{AB}$ & $330.108 \mathrm{AB}$ \\
\hline 3 & $28.318 \mathrm{~A}$ & $61.935 \mathrm{~A}$ & $109.930 \mathrm{~A}$ & $159.158 \mathrm{AB}$ & $187.848 \mathrm{~A}$ & $299.858 \mathrm{~A}$ \\
\hline 4 & $49.938 \mathrm{~B}$ & $93.874 \mathrm{~B}$ & $116.760 \mathrm{AB}$ & $167.688 \mathrm{AB}$ & $206.786 \mathrm{AB}$ & $324.384 \mathrm{AB}$ \\
\hline 5 & $41.119 \mathrm{~B}$ & $64.495 \mathrm{~A}$ & $112.712 \mathrm{~A}$ & $178.993 \mathrm{~B}$ & $195.604 \mathrm{AB}$ & $326.479 \mathrm{AB}$ \\
\hline 6 & $29.472 \mathrm{~A}$ & $67.481 \mathrm{~A}$ & $113.419 \mathrm{~A}$ & $144.668 \mathrm{~A}$ & $188.490 \mathrm{~A}$ & $298.826 \mathrm{~A}$ \\
\hline CV (\%) & 12.31 & 16.01 & 5.97 & 8.71 & 6.24 & 5.45 \\
\hline
\end{tabular}

Note. Averages followed by the same letter in the column do not differ statistically by Tukey test at $5 \%$ probability. CV: coefficient of variation.

The correlation results between electrical conductivity in combination of 25 seeds with 25 and $50 \mathrm{~mL}$, and 50 seeds with 25 and $50 \mathrm{~mL}$ between most immersion periods and seedling emergence data indicated a significant correlation between the tests (Table 4).

The combination of 25 seeds $50 \mathrm{~mL}^{-1}$ for 6 hour imbibition period had significant correlation with seedling emergence test, this result agrees with the data in Table 3 . Thus, it was estimated that the electrical conductivity test can be used instead of emergence of field seedlings for chia seeds. The advantage of this test is that it can be carried out in a shorter period of time. This occurrence is in agreement with Torres, Paiva, Almeida, Benedito, and Carvalho (2015) when reporting that the electrical conductivity test showed a highly significant correlation with the seedling emergence test in the field for Coriandrum sativum L., Portuguese, Super Verdão, Tabocas and Verdão.

In the present study, the fact that there are reduced and non-significant correlation coefficients between the different electrical conductivity and seedling emergence tests does not lead to the discarding of this test for future works on chia seeds. 
Table 4. Pearson correlation coefficient (r) between the results of the electrical conductivity tests in the combinations 25 seeds 25,50 and $75 \mathrm{~mL}^{-1}, 50$ seeds 25,50 and $75 \mathrm{~mL}^{-1}$ per 1, 2, 4, 6, 8 and 24 hours of imbibition, with the emergence test of chia seedlings

\begin{tabular}{|c|c|c|c|c|c|c|}
\hline \multirow{3}{*}{ Period of soaking } & \multicolumn{6}{|c|}{ Emergence } \\
\hline & \multicolumn{3}{|c|}{25 seeds } & \multicolumn{3}{|c|}{50 seeds } \\
\hline & $25 \mathrm{~mL}$ & $50 \mathrm{~mL}$ & $75 \mathrm{~mL}$ & $25 \mathrm{~mL}$ & $50 \mathrm{~mL}$ & $75 \mathrm{~mL}$ \\
\hline $1 \mathrm{~h}$ & $-0.49^{*}$ & $-0.34^{\mathrm{ns}}$ & $-0.59 * *$ & $-0.64 * *$ & $-0.67 * *$ & $-0.04^{\mathrm{ns}}$ \\
\hline $2 \mathrm{~h}$ & $-0.66^{* *}$ & $-0.43 *$ & $-0.34^{\mathrm{ns}}$ & $-0.43 *$ & $-0.67 * *$ & $-0.22^{\mathrm{ns}}$ \\
\hline $4 \mathrm{~h}$ & $-0.53 * *$ & $-0.49^{*}$ & $-0.40^{\mathrm{ns}}$ & $-0.48 * *$ & $-0.68 * *$ & $-0.34^{\mathrm{ns}}$ \\
\hline $6 \mathrm{~h}$ & $-0.53 * *$ & $-0.67 * *$ & $-0.47 *$ & $-0.59 * *$ & $-0.71 * *$ & $-0.41 *$ \\
\hline $8 \mathrm{~h}$ & $-0.37^{\text {ns }}$ & $-0.23^{\mathrm{ns}}$ & $-0.51 *$ & $-0.59 * *$ & $-0.63 * *$ & $-0.43 *$ \\
\hline $24 \mathrm{~h}$ & $-0.30^{\text {ns }}$ & $-0.51 *$ & $-0.61 * *$ & $-0.51 * *$ & $-0.24^{\mathrm{ns}}$ & $-0.49 *$ \\
\hline
\end{tabular}

Note. ${ }^{\text {ns }}$ not significant, $* *$ significant at $1 \%$ and $*$ significant at $5 \%$ probability.

In a general analysis of the results, the combination with 25 seeds with $50 \mathrm{~mL}$ of water at $20{ }^{\circ} \mathrm{C}$ for 6 hours and the combination of 50 seeds with $50 \mathrm{~mL}$ of water at $20{ }^{\circ} \mathrm{C}$ for 24 hours were adequate to conduct the conductivity test in chia seeds. In a study with canola seeds, Milani, Menezes, and Lopes (2012), verified that the electrical conductivity test was efficient to evaluate the physiological potential of canola seeds, under the combination of 50 seeds immersed in $25 \mathrm{~mL}$ of deionized water. In this context, we estimated the standardization of an electrolyte leaching test, using a smaller number of seeds and a quantity of water that favors the leachate reading without any over or underestimation of values in shorter periods of time and compatible with the routine of seed analysis laboratories.

\section{Conclusion}

The electrical conductivity test in the combination of 25 seeds using $50 \mathrm{~mL}$ of water in 6-hour of soaking period, as well as the combination of 50 seeds using $50 \mathrm{~mL}$ of water for 24 hours of soaking were efficient in stratifying chia seeds in different levels of vigor.

\section{References}

Araujo, F. R., Zonta, J. B., Araujo, E. F., Heberle, E., \& Zonta, F. M. G. (2011). Teste de condutividade elétrica para sementes de feijão-mungo-verde. Revista Brasileira de Sementes, 33(1), 123-130. https://doi.org/ 10.1590/S0101-31222011000100014

Brasil. (2009). Ministério da Agricultura, Pecuária e Abastecimento. Regras para análise de sementes (p. 399). Secretaria de Defesa Agropecuária. Brasília: Mapa/ACS. Retrieved from http://www.agricultura.gov.br/ assuntos/insumos-agropecuarios/arquivos-publicacoes-insumos/2946_regras_analise_sementes.pdf

Capitanni, M. I., Sportorno, V., Nolasco, S. M., \& Tomás, M. C. (2012). Physicochemical and functional characterization of by-products from chia (Salvia hispanica L.) seeds of Argentina. Food Science and Technology, 45(1), 94-102. https://doi.org/10.1016/j.lwt.2011.07.012

Carvalho, C., \& Novembre, A. D. L. C. (2011). Avaliação da qualidade de sementes de fumo, nuas e revestidas, pelo teste de condutividade elétrica. Revista Brasileira de Sementes, 33, 177-185. https://doi.org/10.1590/ S0101-31222011000100020

Cruz, S. M., Nery, M. C., Rocha, A. S., Von Pinho, E., Andrade, P. C. R., \& Dias, D. C. F. S. (2013). Vigor tests for evaluation of crambe (Crambe abyssinica Hochst) seed quality. Journal of Seed Science, 35(4), $485-494$. https://doi.org/10.1590/S2317-15372013000400010

Garcéz, Y. J. (2013). La chía (Salvia hispanica L.), una fuente de nutrientes para el desarrollo de alimentos Saludables. Alimentación y Nutrición (p. 43). Corporación Universitaria Lasallista, Facultad de Ingenierías. Retrieved from http://repository.lasallista.edu.co/dspace/bitstream/10567/1043/1/La_chia_salvia_hispanica_ L_desarrollo_alimentos_saludables.pdf

Martins, C. C., Martinelli-Senem, A., Castro, M. M., Nakagawa, J., \& Cavariani, C. (2002). Comparação entre métodos para a avaliação do vigor de lotes de sementes de couve-brócolos (Brassica oleracea L.var. italica PLENK). Revista Brasileira de Sementes, 24(2), 96-101. https://doi.org/10.1590/S0101-312220020001 00016 
McDonald, M. B. (1999). Seed deterioration: Physiology, repair and assessment. Seed Science and Technology, 22(3), 531-539. http://cat.inist.fr/?amodele=affichen\&cpsidt=1898410

Milani, M., Menezes, N. L., \& Lopes, S. J. (2012). Teste de condutividade elétrica para avaliação do potencial fisiológico de sementes de canola. Revista Ceres, 59, 374-379. https://doi.org/10.1590/S0034-737X20120 00300012

Nakagawa, J. (1999). Testes de vigor baseados no desempenho das plântulas. In F. Krzyzanowski, R. D. Vieira, \& J. B. França-Neto (Eds.), Vigor de sementes: Conceitos e testes (Cap. 2, pp. 2-24). Londrina: ABRATES.

Souza, R. H. V., Villela, F. A., \& Aumonde, T. Z. (2013). Methodologies based on seedling performance for vigor assessment of pumpkin seed. Journal of Seed Science, 35(3), 374-380. https://doi.org/10.1590/S231715372013000300015

Souza, R. S., \& Chaves, L. H. G. (2016). Germinação e desenvolvimento inicial das plântulas de chia (Salvia hispanica L) irrigadas com água salina. Revista Espacios, 37(31), 25. Retrieved from http://www.revistaespacios.com/a16v37n31/16373125.html

Stefanello, R., Neves, L., Abbad, M., \& Viana, B. (2015). Germination and vigor of chia seeds (Salvia hispanica L. Lamiaceae) under different temperatures and light conditions. Revista Brasileira de Plantas Medicinais, 17(4), 1182-1186. https://doi.org/10.1590/1983-084x/15_043

Torres, S. B., \& Bezerra Neto, F. (2009). Teste de envelhecimento acelerado para avaliação do potencial fisiológico de sementes de urucum. Horticultura Brasileira, 27, 55-58. https://doi.org/10.1590/S010205362009000100011

Torres, S. B., \& Pereira, R. A. (2010). Condutividade elétrica em sementes de rúcula. Revista Brasileira de Sementes, 32(4), 58-70. https://doi.org/10.1590/S0101-31222010000400007

Torres, S. B., Paiva, E. P., Almeida, J. P. N., Benedito, C. P., \& Carvalho, M. C. (2015). Teste de condutividade elétrica na avaliação da qualidade fisiológicade sementes de coentro. Revista Ciência Agronômica, 46(3), 622-629. https://doi.org/10.5935/1806-6690.20150046

Vanzolini, S., \& Nakagawa, J. (2005). Teste de condutividade elétrica em sementes de amendoim. Revista Brasileira de Sementes, 27(2), 151-158. https://doi.org/10.1590/S0101-31222005000200022

Vazquez, G. H., Bertolin, D. C., \& Spegiorin, C. N. (2011). Testes de envelhecimento acelerado e de condutividade elétrica para avaliar a qualidade fisiológica de sementes de sorgo (Sorghum bicolor (L.) Moench). Revista Brasileira de Biociências, 9(1), 18-24. Retrieved from http://www.ufrgs.br/seerbio/ojs/ index.php/rbb/article/view/1504/993

Vieira, R. D., \& Krzyzanowski, F. C. (1999). Teste de condutividade elétrica. In F. Krzyzanowski, R. D. Vieira, \& J. B. França-Neto (Eds.), Vigor de sementes: conceitos e testes (Cap. 4, pp. 1-26). Londrina: ABRATES.

Vieira, R. D., Penariol, A. L., Perecin, D., \& Panobianco, M. (2002). Condutividade elétrica e teor de água inicial das sementes de soja. Pesquisa Agropecuária Brasileira, 37(9), 1333-1338. https://doi.org/10.1590/S0100204X2002000900018

\section{Copyrights}

Copyright for this article is retained by the author(s), with first publication rights granted to the journal.

This is an open-access article distributed under the terms and conditions of the Creative Commons Attribution license (http://creativecommons.org/licenses/by/4.0/). 